\title{
Mitos Seksualitas dalam Iklan
}

\author{
Jemmy Junius Pah \\ Program Studi Ilmu Komunikasi Kalbis Institute \\ Email: jemmypah@gmail.com
}

\begin{abstract}
ABSTRAK
Penelitian ini bertujuan untuk membongkar mitos seksualitas pada iklan cetak LYNX versi The Cleaner You Are The Dirtier You Get yang hanya menampilkan sosok model wanita seksi tanpa menyertakan model lakilaki. Penelitian ini merupakan penelitian kualitatif. Metode analisis semiotika Roland Barthes digunakan untuk mengetahui makna dari tanda-tanda yang ada pada iklan dan ideologi yang tersembunyi di balik iklan. Setelah menganalisis iklan LYNX versi The Cleaner You Are The Dirtier You Get, peneliti menemukan mitos seksualitas pada berbagai rangkaian penanda (signifier) dan petanda (signified) pada iklan. Penggunaan ikon-ikon seksualitas, seperti model wanita seksi, memperlihatkan adanya eksploitasi terhadap perempuan baik secara fisik maupun nonfisik. Adapun ideologi yang tersembunyi di balik iklan ini adalah konsumerisme, patriarkal, dan kapitalisme.
\end{abstract}

Kata Kunci: Mitos seksualitas, iklan, semiotika, kapitalisme, konsumerisme, patriarkal

\begin{abstract}
This study aims to dismantle the myth of sexuality in the print ads LYNX The Cleaner You Are The Dirtier You Get version which is shows only the figure of a sexy woman without the male. This research is a qualitative research. The semiotic analysis of Roland Barthes is used to find out the meaning of the signs on the ads and the ideologies hidden behind the ad. After analyzing the LYNX advertisement version The Cleaner You Are The Dirtier You Get version, the writer found the myth of sexuality on various series of signifiers and signified on that ads. Thus, the use of sexuality icons, such as sexy female models, shows exploitation of women both physically and nonphysically. Meanwhile, the ideology hidden behind this ad is consumerism, patriarchal, and capitalism
\end{abstract}

Keyword: sexuality myth, advertising, semiotics, capitalism, consumerism, patriarchal

\section{PENDAHULUAN}

Dengan melihat bahwa tujuan utama iklan adalah untuk mempersuasi konsumen agar menggunakan sebuah produk atau jasa, maka penggunaan cara baik strategi maupun bentuk iklan yang disampaikan menjadi sangat bervariatif. Setiap produk berlomba-lomba agar tidak tersaingi produk lainnya. Berbagai cara dilakukan, salah satunya dengan cara memanfaatkan unsur seksualitas wanita. Artinya, tubuh perempuan tidak ditampilkan apa adanya sesuai fungsi biologis atau dalam artian normal dan tidak berlebihan, tapi dibentuk atau dikonstruksi kembali sesuai selera pasar. Penggunaan daya tarik seksual pada iklan antara lain bertujuan memancing naluri seksual konsumen/khalayak untuk mendapatkan perhatian atau rangsangan, mempertahankan daya ingat konsumen terhadap sebuah iklan dalam waktu lama, dan memengaruhi sikap konsumen serta guna meningkatkan minat beli konsumen.

Citation : Pah, Jemy Junius. (2018). "Mitos Seksualitas dalam Iklan”. Nyimak Journal of Communication, 2(1): 1-16. 
Salah satu produk yang memanfaatkan unsur seksualitas dalam iklannya adalah LYNX. LYNX adalah nama lain dari AXE yang digunakan di Irlandia dan Inggris karena memiliki kendala hak cipta. Sebagai produk perawatan tubuh untuk pria, LYNX diproduksi perusahaan multinasional Unilever. Produk ini menyasar konsumen laki-laki berusia 15-35 tahun, yang tergolong ke dalam kategori youth dengan level gaya hidup menengah ke atas, tinggal di daerah perkotaan sekaligus memiliki hasrat untuk mendapatkan serta mempunyai hubungan khusus dengan perempuan yang mereka idamkan (Octavia, 2015; Lasido, 2016).

Produk LYNX/AXE sendiri diluncurkan pertama kalinya pada tahun 1983 di Perancis. Produk ini sukses di Perancis dan dewasa ini pun bisa dengan mudah ditemui di lebih dari 60 negara dan menjadi deodoran nomor satu di pasar Eropa dan Amerika Latin. Produk ini juga sudah dikenal dengan baik di Amerika Serikat dan Asia. Sementara di Indonesia, produk AXE telah menjadi produk terkemuka dalam segmen deodoran pria.

Strategi pemasaran yang diusung oleh LYNX ialah strategi yang memiliki konsep utama tentang Mating Game. Strategi ini ditujukan untuk target konsumen LYNX berusia 15-35 tahun (youth). Berdasarkan riset yang telah dilakukan AXE Research Lab, kaum youth yang berjenis kelamin pria adalah kaum yang sedang memiliki hasrat mendapatkan wanita yang mereka idamkan dan ingin mempunyai hubungan khusus dengan wanita yang mereka idamkan.

Dengan demikian, unsur seksualitas menjadi daya tarik terbesar pada iklan LYNX dalam hal memancing perhatian konsumen sehingga diharapkan konsumen akan tertarik dan membeli produk tersebut (Boddewyn, 1991). Lebih jauh lagi, pada iklan LYNX terjadi proses komodifikasi yang terlihat dari tubuh perempuan yang dieksploitasi sedemikian rupa baik secara fisik maupun nonfisik. Ekploitasi tubuh secara fisik terlihat dari beberapa bagian tubuh yang diekspose, seperti bibir, pundak, dada, paha, disertai bahasa tubuh dan ekspresi yang menunjang terbentuknya image sexy pada iklan LYNX. Sementara secara nonfisik, eksploitasi ditunjukkan dengan menampilkan perempuan dalam berbagai karakter (realitas kedua), seperti mudah tergoda laki-laki, seksi, dan agresif (Kasiyan, 2007).

Berdasarkan penjelasan di atas, peneliti berpendapat bahwa penggunaan seksualitas dalam iklan merupakan sebuah fenomena yang menarik untuk dikaji. Penggunaan unsur seksualitas dalam iklan seakan-akan mempunyai mitos yang di dalamnya dipercaya terkandung muatan ideologi tersembunyi yang diyakini dapat memengaruhi dan menciptakan pemahaman di benak khalayak mengenai pesan dan produk yang diiklankan. Atas dasar itulah penelitian ini hendak melihat dan membongkar bagaimana mitos seksualitas dalam iklan LYNX versi The Cleaner You Are The Dirtier You Get. 


\section{KERANGKA TEORI}

\section{Iklan dan Konstruksi Realitas}

Iklan telah menjadi bagian yang tidak terpisahkan dari kehidupan manusia. Mulai dari bangun tidur sampai saat akan kembali tidur kita pasti akan menjumpai iklan, karena iklan ada di mana-mana. Secara sederhana, iklan merupakan sebuah informasi yang disuguhkan oleh produsen pada masyarakat dengan harapan agar khalayak mau mengkonsumsi produk yang ditawarkan. Tapi lebih jauh lagi, iklan bukan hanya sekedar memberikan informasi, tetapi juga memanipulasi psikologis konsumen secara persuasif untuk mengubah sikap dan pikiran sehingga bersedia membeli/menggunakan produk yang ditawarkan. Dengan segala kreativitasnya, iklan menjadi unsur penting dalam kehidupan sosial. Iklan bukan hanya sebagai alat pemasaran produk, tetapi iklan juga telah menjual nilai-nilai ideal dalam gaya hidup masyarakat.

Kajian mengenai realitas sosial dalam kaitannya dengan iklan menyatakan bahwa iklan bukan cermin realitas yang jujur. Iklan adalah cermin yang cenderung mendistorsi, membuat menjadi cemerlang, melebih-lebihkan dan melakukan seleksi atas tanda-tanda atau citracitra. Tanda atau citra itu tidak merefleksikan realitas, tetapi mengatakan sesuatu tentang realitas. Seperti yang dikemukakan Marchand (dalam Noviani, 2002: 53), iklan adalah sebuah cermin masyarakat, A Mirror on the Wall, yang lebih menampilkan tipuan-tipuan yang halus serta bersifat terapetik daripada menampilkan refleksi-refleksi realitas sosial.

\section{Tanda, Makna, dan Mitos dalam Iklan}

Piliang (2003: 264) menjelaskan bahwa Iklan merupakan ajang permainan tanda, karena iklan selalu berisi unsur-unsur tanda berupa objek yang diiklankan, konteks berupa lingkungan, orang atau makhluk lainnya yang memberikan makna pada objek, serta teks yang memperkuat makna, meskipun yang terakhir ini (teks) tak selalu hadir dalam iklan. Iklan senantiasa bermain-main dalam ketiga elemen tanda tersebut (objek, konteks, dan teks) yang mendukung satu sama lain. Dalam penelitian tentang iklan, analisis mengenai konteks yang ditawarkan merupakan aspek yang sangat penting, sebab lewat konteks tersebutlah dapat dilihat berbagai persoalan sosial yang ada di balik sebuah iklan.

Dalam kajian untuk mengungkap makna dalam iklan, Williamson (dalam Bignell, 1997: 33) menjelaskan bahwa ketika masyarakat membeli sebuah produk maka ia akan disuruh berpartisipasi mengikuti ideologi yang disuguhkan dalam melihat diri dan dunia di sekitarnya. Lebih lanjut, Bignell (1997: 34) menjelaskan: "The aim of ads is to engage us in their structure of meaning, to encourage us to participate by decoding their linguistic and visual signs and to enjoy this decod-ing activity. Ads make use of signs, codes, and social myths which are 
already in circulation, and ask us to recognise and often to enjoy them. At the same time that we are reading and decoding the signs in ads, we participate in the structures of meaning that ads use to represent us, the advertised product, and society. this claim would be illegal in many societies anyway. Instead this message is communicated by the structure of signs in the ad. by the way that we are asked to decode the ad's mythic meaning."

Sementara mitos ialah suatu bentuk pesan atau tuturan yang harus diyakini kebenarannya tetapi tidak dapat dibuktikan. Mitos bukan konsep atau ide, namun merupakan suatu cara pemberian arti (Iswidayati, 2006: 4-5). Secara etimologis, mitos merupakan suatu jenis tuturan meskipun tentunya bukan sembarang tuturan. Mitos adalah suatu sistem komunikasi, yakni suatu pesan (message). Mitos sendiri tidak didefinisikan oleh objek pesan, tapi dengan cara menuturkan pesan tersebut. Contoh: mitos tentang pohon tidak hanya menjelaskan tentang pohon secara kasat mata, tetapi yang penting adalah cara menuturkan tentang pohon tersebut.

\section{Seksualitas dalam Iklan}

Shimp (2003: 481-482) menjelaskan bahwa daya tarik seksual mempunyai peran-peran potensial. Pertama, materi seksual pada periklanan bertindak sebagai daya tarik untuk menarik perhatian sekaligus mempertahankan perhatian tersebut untuk waktu lebih lama, sering kali mempertunjukkan model yang menarik dalam pose merangsang. Ini disebut "peran kekuatan untuk menghentikan" dari seks.

Peran potensial kedua ialah "meningkatkan ingatan" terhadap pesan. Riset menunjukkan bahwa iklan berdaya tarik seksual/simbolisme dapat meningkatkan ingatan jika sesuai dengan kategori produk dan pelaksanaan kreatif iklan. Daya tarik seksual menghasilkan ingatan yang lebih baik apabila pelaksanaan periklanan mempunyai hubungan yang tepat dengan produk yang diiklankan.

Peran ketiga ialah membangkitkan tanggapan emosional, seperti perasaan arousal (merangsang) atau nafsu. Reaksi-reaksi ini dapat meningkatkan pengaruh persuasif iklan, dengan kebalikannya, bisa menimbulkan perasaan negatif seperti rasa jijik, rasa malu, atau perasaan tidak senang.

Akibatnya, bentuk iklan yang dimuat masih berada di garis abu-abu antara pornografi dengan karya seni. Makna eksplisit adalah persoalan gaya hidup global sementara makna yang implisit ialah adanya kecenderungan tindakan seksual yang permisif (Syuderajat, 2016). Dengan kata lain unsur seksualitas beserta sensualitas cenderung dimanfaatkan untuk mendorong minat beli khalayak terhadap produk yang diiklankan tersebut (Rukiah, 2017; Sherman \& Quester, 2005). 


\section{Ekonomi Politik Media dan Komodifikasi}

Mosco (2009: 14) menyatakan bahwa di dalam pendekatan ekonomi politik media terdapat tiga hal yang perlu diperhatikan, yaitu komodifikasi, spasialisasi, dan strukturasi. Komodifikasi ialah proses yang berlangsung dalam industri media yang selalu memperhatikan bentukbentuk komoditi dalam komunikasi melalui isi media. Proses komodifikasi dalam komunikasi terjadi lewat penciptaan pesan dari sejumlah data menjadi produk-produk yang laku dijual. Bagi Mosco komodifikasi adalah cara kapitalisme mencapai tujuan untuk mengakumulasi kapital dan nilai melalui transformasi penggunaan nilai-nilai ke dalam sebuah sistem tukar. Proses komodifikasi dalam media melalui dua tahap. Pertama, proses produksi program. Kedua, penggunaan periklanan media untuk menciptakan komodifikasi di dalam proses ekonomi

Dalam masyarakat komoditas (terutama kapitalisme lanjut), tubuh (body), tanda-tanda tubuh (body signs), dan potensi libido di balik tubuh (libidinal value), merupakan bagian yang tak terpisahkan dari budaya komoditas yang membentuk semacam sistem libidonomics (libido = energi hasrat, nemein = mendistribusikan), yaitu sistem ekonomi yang mengeksploitasi setiap potensi libido guna memperoleh keuntungan ekonomi semata (produsen, programer, peng-copy, penjual, media). Libidonomi mengkondisikan logika operasionalnya setidaknya pada tiga tingkatan politik tubuh (body politics) yang saling berkaitan satu sama lain.

Pertama, persoalan ekonomi politik tubuh (political economy of the body), yaitu bagaimana aktivitas tubuh perempuan digunakan di dalam berbagai aktivitas ekonomi berdasarkan konstruksi sosial atau ideologi tertentu. Kedua, persoalan ekonomi politik tanda atau political economy of sign, yaitu bagaimana perempuan hanya diproduksi sebagai tandatanda (signs) pada sebuah sistem pertandaan (sign system), khususnya di dalam masyarakat kapitalis, yang membentuk citra (image), makna (meaning), dan identitas (identity) diri mereka. Ketiga, persoalan ekonomi politik hasrat (political economy of desire), yaitu bagaimana hasrat perempuan disalurkan atau direpresi di dalam berbagai bentuk komoditi, khususnya komoditi hiburan dan tontonan (Piliang, 2003: 165-166).

Penggunaan 'tubuh' dan 'representasi tubuh' (body sign) sebagai komoditi (komodifikasi) pada media-media hiburan masyarakat kapitalis telah mengangkat berbagai persoalan yang tidak saja menyangkut 'relasi ekonomi' (peran ekonomi perempuan), akan tetapi lebih jauh 'relasi ideologi', yaitu bagaimana penggunaan tubuh dan citra tersebut menandakan suatu relasi sosial-khususnya relasi gender-yang dikonstruksi berdasarkan sistem ideologi tertentu (Benedicta, 2011; Kasiyan, 2007) 


\section{Konstruksi Ideologi Konsumerisme, Patriarkal, dan Kapitalisme dalam Iklan}

Kapitalisme pada intinya adalah sebuah ideologi yang berbicara mengenai penanaman modal dengan ekspektasi penuaian laba. Kapitalisme diartikan sebagai rangkaian proses yang terakumulasi dan pencarian terus menerus guna memperluas profitabilitas. Perusahaan dapat memperbanyak keuntungannya dengan menekan biaya dan meningkatkan penjualan. Dinamika kapitalisme meliputi pencarian tanpa akhir dalam memperluas pasar dan mengamankan segala sumber demi penekanan biaya. Kapitalisme menekankan pada peranan pasar, dan sebagai konsekuensinya, cenderung kejam terhadap kesejahteraan manusia.

Kapitalisme modern memerlukan orang-orang yang terdominasi oleh gaya hidup konsumerisme, suatu gaya hidup yang telah distandarisasi kekuatan media. Industri media dengan kejam mempromosikan konsumerisme, dengan menekankan pada apa yang dikatakan sebagai gaya hidup yang pantas. Konsumerisme adalah pola pikir dan tindakan di mana orang membeli barang bukan karena kebutuhan, melainkan karena bisa memberi kepuasan. Praktik-praktik konsumsi pun akhirnya menjadi gaya hidup publik. Konsumsi menjadi cara pandang baru seiring dengan terus beroperasinya industri lintas negara. Konsumerisme menjadi sebuah ideologi baru yang mewajibkan manusia mengkonsumsi komoditas sehingga eksistensinya diakui oleh masyarakat (Soedjatmiko, 2008: 88).

Kegiatan mengkonsumsi di dunia modern terkait dengan kegiatan belanja. Berbelanja dilakukan manusia agar memperoleh barang/hal yang dibutuhkan guna memenuhi kebutuhan hidupnya. Bagi konsumerisme, bukan soal ada atau tidaknya uang untuk shopping. Konsumerisme yang semula ditujukan terhadap kelompok "lebih" di masa sekarang juga ditujukan kepada kelompok yang "kurang". Dalam arti tertentu, kelompok ini mendapat kesempatan pula untuk menikmatinya lewat jasa kredit.

Pada sisi lainnya, iklan telah mengonstruksi masyarakat konsumer menjadi kelompok gaya hidup, yang pola kehidupannya diatur berdasarkan tema, citra, dan makna simbolik tertentu (Piliang, 2003). Setiap kelompok gaya hidup menciptakan ruang sosial yang di dalamnya gaya hidup dikonstruksi. Pierre Bourdieu memakai istilah habitus untuk menjelaskan semacam kebiasaan yang berkembang di dalam setiap kelompok gaya hidup, yang menyebabkan seorang anggota kelompok gaya hidup tertentu lebih memilih memakai LYNX shower gel sewaktu mandi daripada memakai sabun batangan biasa.

Sementara dalam budaya patriarkal, tubuh perempuan dikonsumsi sebagai objek pandangan, objek sentuhan, objek seksual, objek hasrat laki-laki, serta objek ideologi (Priyatna, 2006: 80). Umumnya, perempuan dikonsumsi serta dipersepsi sebagai objek, dan objek dalam arti harafiah ialah penerima tindakan/lakuan. Hal ini semakin menguatkan bahwa perempuan harus terus berjuang untuk bisa lepas, atau setidaknya tak dieksploitasi secara 
semena-mena oleh kungkungan patriarkal beserta kapitalisme yang menggunakan keperempuannya (Nuraina, 2011; Siswati, 2014; Hariyanto, 2009; Winarni, 2010; Murwani, 2010).

\section{Semiotika Pesan Komunikasi}

Di Roland tangan Barthes, semiotika digunakan secara luas pada berbagai bidang sebagai alat untuk berpikir kritis. Pernyataan Barthes yang paling dikenal adalah La Mort de l'auteur atau matinya si penulis, yang menggarisbawahi bahwa tak ada otoritasi interpretasi dan interpretasi bisa terus berjalan. Dalam Mythology, secara terperinci Barthes menjelaskan bahwa sistem signifikasi tanda terdiri atas relasi $(\mathrm{R}=$ relation) antara tanda $(\mathrm{E}=$ expression $)$ dengan maknanya ( $C$ = content). Sistem signifikasi tanda itu dibagi menjadi sistem pertama (primer) yang disebut sistem denotatif dan sistem kedua (sekunder) yang dibagi lagi menjadi dua: sistem konotatif dan sistem metabahasa (Barthes, 2009: 158-162).

Denotasi merupakan tingkat pertandaan yang menjelaskan hubungan antara penanda dan petanda, atau antara tanda dan rujukannya pada realitas, yang dapat menghasilkan makna eksplisit, langsung, dan pasti. Dalam hal ini, makna denotasi (denotative meaning) adalah makna pada apa yang tampak. Misalnya, foto wajah Soeharto berarti wajah Soeharto yang sesungguhnya. Denotasi adalah tanda yang penandaannya memiliki tingkat konvensi atau kesepakatan yang tinggi. Sedangkan konotasi adalah tingkat pertandaan yang menjelaskan hubungan antara penanda dan petanda, yang di dalamnya beroperasi makna tidak eksplisit, tak langsung dan tidak pasti (terbuka terhadap berbagai kemungkinan). la menciptakan makna lapis kedua yang terbentuk ketika penanda dikaitkan dengan berbagai aspek psikologis, seperti perasaan, emosi, keyakinan. Misal tanda "bunga” mengkonotasikan "kasih sayang". Konotasi dapat menghasilkan makna lapis kedua yang bersifat implisit, tersembunyi, yang disebut makna konotatif (conotative meaning).

Konotasi yang mantap selanjutnya dapat berkembang menjadi mitos, yaitu makna tersembunyi yang secara sadar disepakati komunitas tertentu. Mitos yang mantap dapat berkembang menjadi sebuah ideologi, yaitu sesuatu yang mendasari pemikiran komunitas sehingga secara tidak sadar pandangan mereka dipengaruhi ideologi tersebut (Barthes, 2009: 109). Menurut Barthes, pada tingkatan denotasi, bahasa menghadirkan konvensi/ kode-kode sosial yang eksplisit, yakni kode-kode yang makna tandanya segera naik ke permukaan berdasarkan relasi penanda dan petandanya. Sebaliknya, pada tingkatan konotasi bahasa menghadirkan kode-kode yang makna tandanya bersifat implisit, yaitu sistem kode yang tandanya memiliki makna-makna tersembunyi. Makna tersembunyi ini adalah makna yang menurut Barthes sebagai kawasan dari ideologi atau mitologi. 
Dalam perkembangannya, metode semiotika Barthes ini banyak digunakan untuk menganalisis iklan-iklan yang dianggap menyebarkan/menyimpan ideologi kepentingan tertentu (Noor \& Wahyuningratna, 2017; Mukti, Sultan dan Bahfiarti, 2015; Wulandari \& Hamdani, 2017; Malika \& Lestari, 2018; Putri, 2014).

\section{METODE PENELITIAN}

Objek penelitian ini adalah iklan cetak LYNX versi The Cleaner You Are The Dirtier You Get. Bentuk iklan yang dipilih adalah versi Billboard. Versi ini dipilih karena pemilihan simbol perempuan yang dipilih, bukan model laki-laki sebagaimana dalam versi audiovisualnya. Penelitian ini menggunakan paradigma kritis dan ingin membongkar bagaimana makna penanda, petanda dan mitos Iklan LYNX versi The Cleaner You Are The Dirtier You Get dengan analisis semiotika Roland Barthes. Paradigma kritis dalam penelitian ini dimaksudkan untuk melihat bagaimana ideologi yang terkandung di dalam mitos.

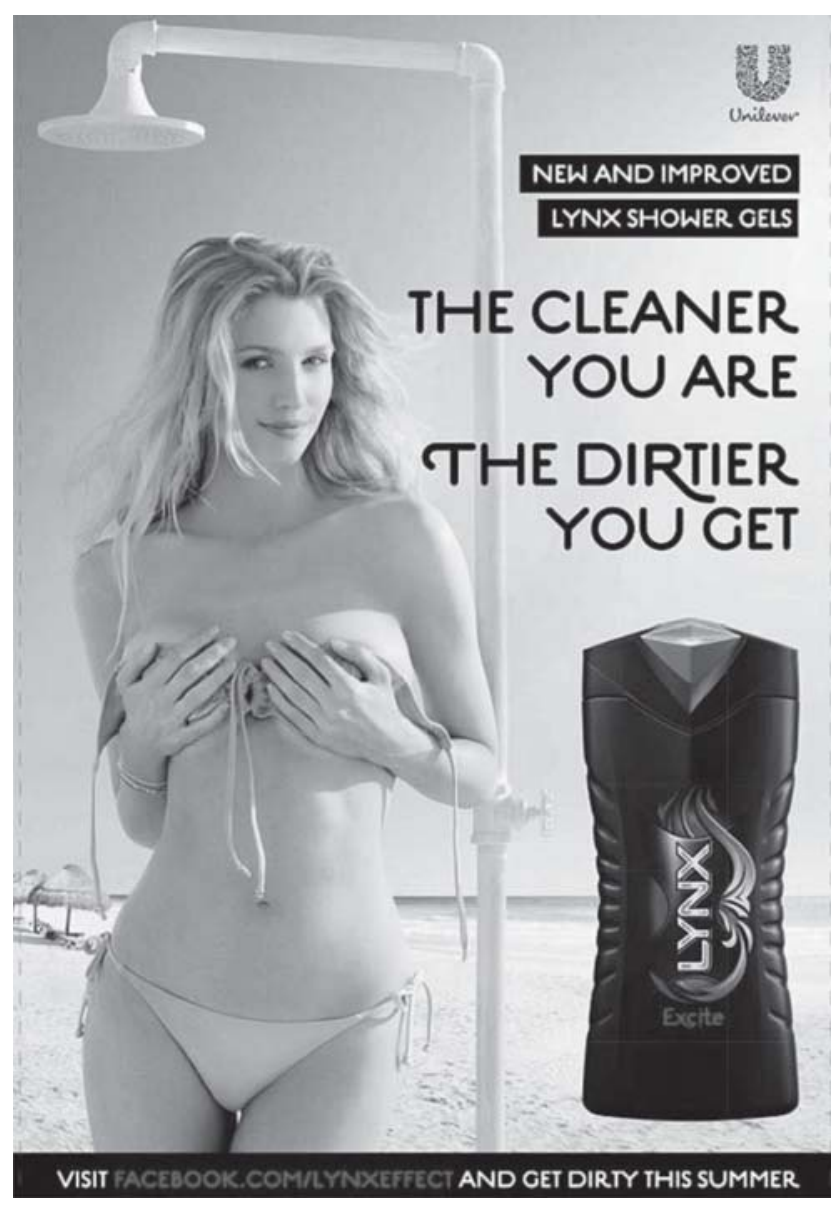

Gambar 1. Tampilan Iklan Cetak LYNX 


\section{HASIL DAN PEMBAHASAN}

Iklan LYNX versi The Cleaner You Are The Dirtier You Get menampilkan latar belakang pantai di Barat. Warna yang dominan dalam iklan ini adalah warna dasar natural/alami yang menawarkan sesuatu yang masih baru. Teks pada iklan yang memadukan warna hitam, putih dan merah, menggambarkan sesuatu yang kuat, elegan, bersih dan excite. Hampir separuh ruang yang ada diisi oleh model iklan perempuan seksi yang mengenakan bikini, yang menawarkan hayalan dan rangsangan seksual bagi konsumen pria yang melakukan aktivitas mandi memakai LYNX shower gel. Pakaian mini atau bikini dikenakan di Barat pada saat Musim Panas untuk kegiatan mandi dan berjemur di pantai, bahkan pada beberapa pantai tertentu di Barat memberi kebebasan kepada pengunjung untuk tidak berbusana.

Latar belakang visualisasi laut yang hijau kebiruan, tenang, dan berwarna sepadan dengan bra dan bikini juga dapat bermakna sebagai kekuatan LYNX/AXE effect yang menggambarkan kedewasaan yang melatarbelakangi iklan LYNX. Hal yang masih baru dan alami atau "perawan" dianggap memilki nilai lebih terutama di negara yang memiliki budaya seks bebas yang sudah tidak begitu menganggap keperawanan sebagai suatu kebanggaan yang dipertahankan hingga menikah. Laut yang tenang menggoda pria pemakai LYNX untuk terjun dan mandi di dalamnya, meskipun laut juga bisa bergelora dan berubah menjadi ganas jika dihembus angin, seperti model wanita yang tenang namun siap bergelora saat dijamah pria pemakai LYNX.

Suasana langit terlihat cerah menggambarkan kebersihan yang dialami jika mandi menggunakan LYNX shower gel. Hal ini juga merujuk pada produk LYNX yang segera diluncurkan di Musim Panas di mana langit terlihat bersih dan tenang. Di bawah visual tagline terdapat botol/kemasan produk LYNX yang bentuknya mirip dengan tubuh wanita seksi, disandingkan sejajar dengan model wanita seksi dengan alur yang dibantu garis imaji yang bisa ditemukan dari shower putih tegak yang menggambarkan pria pemakai Lynx. Di dalam gambaran iklan, keran pada shower ditempatkan lebih dekat dan mengarah dari botol hitam yang menyerupai tubuh perempuan, kemudian arah jalur pipa yang mengarah ke atas dan berbelok menurun hingga mulut shower jatuh mengarah ke dekat wanita seksi itu. Selain mereferensikan perbandingan antara botol berbentuk mirip tubuh wanita dan model wanita seksi, pesan ini menggambarkan bahwa pria membuka keran dan mandi menggunakan LYNX shower gel, ia akan mendapatkan sesosok wanita seksi dan mengalami pengalaman seksual atau "dirty" seperti yang ditawarkan dalam iklan ini. Shower putih yang tegak berdiri (ereksi) ini juga bermakna seksualitas di mana menggambarkan pria atau alat kelamin pria yang telah bersih dan siap melakukan aktivitas seksual oleh karena pengaruh dari penggunaan LYNX shower gel. 
Dengan memakai unsur seksualitas guna menarik perhatian audience, iklan cetak LYNX versi The Cleaner You Are The Dirtier You Get ini menjadikan unsur seksualitas, khususnya perempuan sebagai sebuah penanda (signifier) atas produk (signified). Bentuk kemasan/ botol LYNX yang mirip dengan tubuh wanita seksi mengandung pesan bahwa laki-laki yang mandi memakai LYNX shower gel akan merasakan sensasi seolah-olah sedang memegang tubuh wanita seksi, dan LYNX shower gel ingin menawarkan pemenuhan hasrat seksual lakilaki yang dilakukan dengan mandi memakai LYNX shower gel. karena itu, seorang perancang atau desainer kemasan harus menawarkan usulan bentuk kemasan yang lebih "unik" dari apa yang sudah ada sebelumnya dan tetap dapat diterima sasaran konsumen yang akan dituju (Masri, 2010: 131). Dengan cara ini, hasil akhir yang diinginkan adalah konsumen dapat memperoleh sensasi tersendiri ketika berinteraksi dengan sebuah desain kemasan dari suatu produk.

Memperkuat hal ini, penggunaan slogan The Cleaner You Are The Dirtier You Get adalah pernyataan otoritatif yang menekankan manfaat yang diperoleh para pria pengguna LYNX shower gel. Artinya, mereka tak perlu bersusah payah mengejar wanita (seksi). Cukup memakai LYNX shower gel ketika mandi maka sang wanita dengan sendirinya akan tergoda dan mengejar sang pria. Penggunaan slogan The Cleaner You Are The Dirtier You Get juga merupakan bagian strategi periklanan yang bertujuan menciptakan kesan seksi (maskulinitas) bagi konsumen yang memakai produk LYNX shower gel.

Di tengah-tengah gambar kemasan dan model wanita seksi terdapat objek shower yang tidak sedang digunakan untuk mandi. Guna membedakannya dengan produk parfum yang sudah lebih dikenal oleh publik, penempatan objek shower juga tidak semata-mata sebagai bentuk informasi kepada audience bahwa LYNX shower gel adalah produk sabun mandi cair, melainkan juga secara tidak langsung memberi pesan kepada audience bahwa aktvitas mandi dapat memberikan sensasi dan efek yang tersendiri. Sensasi yang dijanjikan ialah pemenuhan hasrat seksual, terutama saat memegang botol LYNX shower gel, sedangkan efek yang dijanjikan kepada pria yang mandi dengan LYNX shower gel ialah menjadi menggairahkan di mata wanita. Pada akhirnya sang wanita akan tergoda dan mengejar-ngejar pria pemakai LYNX.

Berdasarkan penjelasan di atas mengenai tanda-tanda atau objek-objek seksualitas, pertanyaan yang kemudian muncul adalah wanita seperti apakah yang tergoda dan mengejar pria pemakai shower gel. Untuk menjawab pertanyaan ini, digunakanlah model wanita (seksi) sebagai jawaban yang secara tidak langsung menegaskan bahwa sosok wanita yang "dijanjikan" akan mengejar pria pemakai shower gel adalah wanita seksi. Padahal, jika diamati lebih jauh, model wanita seksi yang mengenakan bikini adalah hal yang wajar 
mengingat iklan versi The Cleaner You Are The Dirtier You Get berlatar belakang pantai, di mana seluruh pengunjung wanita pasti mengenakan bikini. Artinya, menemukan wanita seksi yang mengenakan bikini di daerah pantai adalah hal biasa dan wajar di pantai-pantai negara Barat, dan bahkan tidak mandi dengan shower gel pun seorang pria bisa berkenalan dengan wanita seksi di pantai. Inilah yang peneliti curigai sebagai janji semu yang ditawarkan oleh shower gel kepada audience, khususnya kaum muda laki-laki yang sedang mengalami masamasa penuh gejolak dan pencarian identitas diri.

Peneliti dapat menyimpulkan bahwa pada iklan LYNX versi The Cleaner You Are The Dirtier You Get terdapat upaya eksploitasi terhadap perempuan baik secara fisik maupun nonfisik dengan memanfaatkan tubuh perempuan dan juga hasratnya. Eksploitasi perempuan secara fisik terlihat dalam penggunaan bagian tubuh perempuan sebagai fragmen (tak utuh), seperti bibir, leher, lengan, pundak, dada dan paha. Sementara eksploitasi perempuan secara nonfisik terlihat melalui pembentukan karakteristik model wanita seksi di dalam iklan yang mudah tergoda laki-laki, seksi, percaya diri dan agresif.

Sensualitas dan seksualitas perempuan yang tiba-tiba saja muncul akibat mencium aroma LYNX shower gel bisa dimaknai sebagai kesan atau image seksi pada produk LYNX shower gel. Pada iklan cetak LYNX shower gel, leher, dada, punggung, rambut dan bibir, masih kental diperlihatkan. Citra ini memperkuat anggapan tersirat bahwa sudah sewajarnya perempuan itu diberlakukan sebagai objek pemuasan hasrat seksual laki-laki.

Dalam masyarakat komoditas (terutama kapitalisme lanjut), tubuh (body), tanda-tanda tubuh (body signs), dan potensi libido di balik tubuh (libidinal value), merupakan bagian yang tak terpisahkan dari budaya komoditas yang membentuk semacam sistem libidonomics (libido = energi hasrat, nemein = mendistribusikan), yaitu sistem ekonomi yang mengeksploitasi setiap potensi libido semata untuk memperoleh keuntungan ekonomi (produsen, programer, peng-copy, penjual, media). Libidonomi mengkondisikan logika operasionalnya setidaknya pada tiga tingkat politik tubuh (body politics) yang saling berkaitan satu sama lain (Piliang, 2003: 165).

Selain menggunakan model wanita seksi, jika diamati lebih lanjut, proses komodifikasi tersebut bisa terlihat jelas mulai dari pemilihan bentuk kemasan yang mirip tubuh wanita seksi, penggunaan shower putih yang menggambarkan pria, pemilihan bentuk huruf serta tagline, pemilihan objek pantai, pengunaan warna-warna yang mengarah kepada seksualitas, komposisi garis imajiner dan lain-lain. Kehadiran objek-objek tersebut menandai telah terjadinya transformasi nilai-nilai dari nilai guna menjadi nilai tukar (profit). 
Setelah membongkar mitos seksualitas yang dalam iklan LYNX versi The Cleaner You Are The Dirtier You Get dan proses komodifikasi yang berlangsung, peneliti melihat adanya tiga ideologi yang beroperasi: Konsumerisme, Patriarkal dan Kapitalisme

Pertama, ideologi konsumerisme. Seksualitas perempuan yang munculnya tiba-tiba akibat kesegaran LYNX shower gel dapat memberi kesan LYNX sebagai sebuah produk yang sexy. Ini menguatkan penelitian Tom Reichert bahwa produk-produk terkemuka dan biro iklan terkadang tak hanya menggunakan materi seksual sebagai penguat promosi mereka saja, namun juga memposisikan produk mereka sebagai produk berbau seksualitas (Reichert, 2007). Pada tataran ini, kaum laki-laki seakan dibuai oleh mimpi mudahnya mendapatkan wanita cantik-seksi setelah mandi dan menggunakan produk LYNX shower gel. Bagaimanapun juga, dengan menampilkan unsur-unsur seksualitas pada iklannya, apa yang ditawarkan oleh LYNX pada para konsumennya semata-mata hanya impian semu. Inilah apa yang disebut Umberto Eco teori kedustaan (Piliang, 2003: 45). Artinya, apabila sesuatu tak dapat digunakan untuk mengungkapkan dusta, maka sebaliknya ia tidak dapat pula digunakan mengungkapkan kebenaran (truth); ia pada kenyataannya tak bisa digunakan untuk mengungkapkan apaapa.

Kedua, ideologi patriarkal. Sebagai produk, LYNX bisa dianggap sebagai produk yang merepresentasikan dominasi laki-laki atas perempuan. Frasa The Cleaner You Are The Dirtier You Get menjadi sebuah frasa yang sangat patriarkal karena menandaskan superioritas laki-laki. Pada iklan ini, perempuan berubah menjadi terlihat lebih menarik, seksi, bergairah, dan lebih agresif karena pengaruh LYNX shower gel. Jika dikaji lebih lanjut iklan LYNX versi The Cleaner You Are The Dirtier You Get dengan jelas menampilkan konstruksi yang berbeda tentang perempuan. Jika di dalam iklan lain perempuan dikonstruksi sebagai sosok yang hampir selalu "pasif" di depan laki-laki maka pada iklan LYNX versi The Cleaner You Are The Dirtier You Get sosok perempuan yang ditampilkan adalah sosok perempuan yang 'agresif' di hadapan laki-laki.

Ketiga, ideologi kapitalisme. Penyajian unsur-unsur seksualitas perempuan pada iklan LYNX versi The Cleaner You Are The Dirtier You Get membuktikan bahwa iklan dengan target kaum laki-laki memiliki kekuatan daya saing-daya jual. Akibatnya, eksploitasi tubuh perempuan untuk kepentingan industri menjadi sulit dihindari, terlebih naluri atau hasrat seksual laki-laki yang mudah dibangkitkan oleh keindahan lekuk tubuh perempuan. Pengetahuan pelaku bisnis akan hasrat alamiah manusia tersebut jadi senjata ampuh untuk mengeruk keuntungan melalui eksploitasi tubuh perempuan. 
Pemaparan di atas bisa memberikan sebuah gambaran betapa iklan LYNX telah melakukan semacam penipuan (deception) kepada publik dengan merayakan keseksian, kegairahan, sensualitas dan kepuasan yang bisa ditawarkan oleh sebotol sabun mandi cair. Pada titik ini, ideologi konsumerisme dan kapitalisme berhasil menawarkan janji semu pada kaum laki-laki: mendapat wanita seksi setelah mandi memakai LYNX shower gel (Piliang, 2004). Dengan demikian, iklan produk yang ditampilkan lebih menekankan aspek mitos daripada manfaat yang sebenarnya dari produk tersebut (Hasyim, 2013).

Meskipun iklan cetak ini dibuat dan diedarkan di negara Barat, yang secara terangterangan menjunjung kebebasan dan cenderung menganut seks bebas, pada kenyataannya iklan ini dilarang beredar oleh Advertising Standards Authority (ASA) (Singh, 2012). Sebagian besar pengaduan yang masuk dan diterima ASA menyatakan bahwa iklan tersebut kurang sopan karena secara jelas menonjolkan unsur seksualitas sekaligus merendahkan perempuan. Beberapa keluhan lainnya menyatakan jika iklan tersebut dipajang di berbagai titik yang mudah terjangkau anak-anak. Artinya, meskipun iklan ini dibuat dan dikonsumsi masyarakat Barat yang tak lagi memandang seksualitas sebagai hal tabu untuk diperbincangkan atau dipertontonkan, mereka tetap menjunjung nilai-nilai kesopanan yang berlaku di tengah kehidupan mereka. Akhirnya, hal ini secara jelas memperlihatkan standar ganda masyarakat Barat terkait seksualitas yang dipuji sekaligus dikecam apabila dipertontonkan secara vulgar.

\section{KESIMPULAN}

Pada iklan LYNX versi The Cleaner You Are The Dirtier You Get terdapat rangkaian penanda (signifier) dan petanda (signified) baik secara langsung atau tak langsung mengandung unsur seksualitas. Rangkaian penanda (signifier) yang secara langsung mengarah kepada seksualitas ialah pemakaian model wanita seksi yang mengenakan bikini, penggunaan kata EXCITE yang berarti menggairahkan, dan tagline iklan The Cleaner You Are The Dirtier You Get. Sementara rangkaian penanda (signifier) yang secara tak langsung mengandung unsur seksualitas dapat terlihat pada desain kemasan/botol LYNX shower gel yang sengaja didesain mirip dengan tubuh wanita seksi, objek shower yang mengaitkan aktivitas mandi dengan "kegairahan", dan terutama setting iklan yang berlatar pantai, yang dalam budaya Barat ialah ruang publik di mana setiap orang bebas mengekspresikan seksualitas (tubuh, daya tarik seksual, dan lain sebagainya). Selain itu, rangkaian pemilihan warna pada iklan, khususnya hitam, merah, dan biru hijau, ikut berkorelasi dengan unsur-unsur seksualitas. Penyajian konsep sex appeal pada iklan LYNX versi The Cleaner You Are The Dirtier You Get menunjukkan jika iklan dengan target market kaum laki-laki (youth) akan mudah ditaklukkan 
dengan menampilkan seksualitas (salah satunya wanita seksi) sebagai daya tarik iklan. Hal ini memperlihatkan betapa ikon-ikon seksualitas tetap menjadi andalan dalam budaya massa yang kemudian diproduksi melalui corak produksi kapitalisme.

Dalam menampilkan mitos seksualitas yang membuat perempuan berubah menjadi agresif dan menggoda sang pria pemakai LYNX, kreator iklan sebenarnya mengambil realitas sosial tentang seksualitas yang memang telah ada dalam benak masyarakat sejak dahulu kala, kemudian memformulasikannya agar sesuai dengan keinginan produsen. Karena target sasarannya pria muda (youth) yang cenderung menginginkan wanita yang lebih agresif, citra produk yang dibangun dengan unsur seksualitas kemudian membentuk realitas kedua tentang perempuan yang 'agresif'. Sementara kaum laki-laki selaku pengguna LYNX shower gel, dibuai oleh mimpi kemudahan mendapatkan wanita cantik setelah mandi menggunakan Lynx shower gel, seakan-akan Lynx shower gel sudah "satu paket" dengan model wanita seksi yang ditampilkan dalam iklan. Akhirnya, konsumen hanya membeli "kesegaran" yang ditawarkan model wanita seksi atas produk tersebut, bukan kualitas dari produk yang ditawarkan. Komersialisasi tubuh perempuan pada iklan LYNX versi The Cleaner You Are The Dirtier You Get berangkat dari asumsi mendasar bahwa tubuh perempuan adalah hal yang layak jual (komoditi). Proses komodifikasi ini terlihat dari tubuh perempuan yang dieksploitasi sedemikian rupa dan dijabarkan baik secara fisik maupun nonfisik. Ekploitasi secara fisik ditunjukkan dengan cara mengekspose beberapa bagian tubuh seperti bibir, dada, paha, bahasa tubuh yang menunjang terbentuknya image sexy. Sedangkan secara nonfisik terlihat dengan menampilkan perempuan dalam berbagai karakter (realitas kedua) seperti mudah tergoda, seksi, dan agresif.

\section{REFERENSI}

Barthes, Roland. (2009). Mitologi. Yogyakarta: Kreasi Wacana.

Benedicta, Gabriella Devi. (2011). “Dinamika Otonomi Tubuh Perempuan: Antara Kuasa dan Negosiasi atas Tubuh". Masyarakat (Jurnal Sosiologi), 16(2): 141-156.

Bignell, Jonathan. (1997). Media Semiotics: An Introduction. New York: Manchester University Press.

Boddewyn, Jean J. (1991). "Controlling Sex and Decency in Advertising around the World". Journal of Advertising, 20(4): 25-35.

Hariyanto. (2009). "Gender dalam Konstruksi Media". Komunika, 3(2): 167-183.

Hasyim, Muhammad. (2013). "Mitologisasi Seksualitas dalam Media Iklan Televisi". Jurnal IImu Budaya, 1(1): 77-96. 
Kasiyan. (2007). "Komodifikasi Seks dan Pornografi dalam Representasi Estetika Iklan Komersial di Media Massa". Jurnal Penelitian Humaniora, 12(1): 18-34.

Lasido, Nur Allan. (2016). “Mitos Gaya Hidup Metroseksualitas dalam Iklan Produk Kosmetik Vaseline Men". Jurnal Komunikasi, 10(2): 169-183.

Malika, Ika dan Sinta Petri Lestari. (2018). "Analisis Semiotika Dalam Iklan "Fair And Lovely" Versi Nikah". Jurnal Egaliter, 1(2): 1-17.

Masri, Andry. (2010). Strategi Visual: Bermain dengan Formalistik dan Semiotik untuk Menghasilkan Kualitas Visual dalam Desain. Yogyakarta: Jalasutra.

Mosco, Vincent. (2009). The Political Economy of Communication. London: Sage Publication. Mukti, Imam, M. Iqbal Sultan dan Tuti Bahfiarti. (2015). "Semiotika Ikon Perempuan pada Iklan Mobil dalam Majalah Otomotif Autoexpert". Jurnal Komunikasi KAREBA, 4(3): 344359.

Murwani, Endah. (2010). “Konstruksi ‘Bentuk Tubuh Perempuan’ dalam Iklan Televisi”. Jurnal IImu Komunikasi, 2(1): 10-18.

Noor, Firdaus dan Ratu Nadya Wahyuningratna. (2017). "Representasi Sensualitas Perempuan dalam Iklan New Era Boots di Televisi (Kajian Semiotika Roland Barthes)". IkraithHumaniora, 1(2): 1-10.

Noviani, Ratna. (2002). Jalan Tengah Memahami Iklan: antara Realitas, Representasi, dan Simulasi. Yogyakarta: Pustaka Pelajar.

Nuraina. (2011). "Media, Seksualitas Perempuan dan Pornografi dalam Dominasi Partriarkhi". Jurnal Kybernan, 2(1): 1-16.

Octavia, Ercilia Rini. (2015). “Perempuan dalam Iklan Axe Effect 'Call Me' sebagai Perwujudan Consumer Insight Target Audience". Etnografi, XV(1): 13-32.

Piliang, Yasraf Amir. (2003). Hipersemiotika: Tafsir Cultural Studies atas Matinya Makna. Yogyakarta: Jalasutra.

Piliang, Yasraf Amir. (2004). "Iklan, Informasi, atau Simulasi? Konteks Sosial dan Kultural Iklan." Mediator, 5(1): 63-73.

Priyatna, Aquarini. (2006). Kajian Budaya Feminis: Tubuh, Sastra dan Budaya Pop. Yogyakarta: Jalasutra.

Putri, Ardiyanti Pradhika. (2014). "Representasi Citra Perempuan dalam Iklan Shampoo Tresemme Keratin Smooth di Majalah Femina". eJournal IImu Komunikasi, 2(2): 104-115. Reichert, Tom. (2007). What is Sex in Advertising, Perspective Form Consumer Behaviour and Social Science Research. University of Alabama.

Rukiah, Yayah. (2017). "Citra (Image) Perempuan sebagai Objek Seksualitas dalam Iklan Studi Kasus Iklan Axe". Jurnal Magenta STMK Trisakti, 1(2): 211-221. 
Sherman, Claire and Pascale Quester. (2005). "The Influence of Product/Nudity Congruence on Advertising Effectiveness". Journal of Promotion Management, 11(2/3): 61-89.

Shimp, Terence A. (2003). Periklanan Promosi (Jilid 1). Jakarta: Erlangga.

Singh, Shiv. (15 Maret 2012). A2 Media: TV Advertising In A Digital World. Diakses dari: https://pagetmedia.wordpress.com/2012/03/page/2/

Siswati, Endah. (2014). "Representasi Domestikasi Perempuan dalam Iklan". Jurnal IImu Komunikasi, 11(2): 179-194.

Soedjatmiko, Haryanto. (2003). Saya Berbelanja, Maka Saya Ada: Ketika Konsumsi dan Desain Menjadi Gaya Hidup Konsumeris. Yogyakarta: Jalasutra.

Syuderajat, Fajar. (2016). “Pornografi dalam Iklan: Analisis Isi Iklan dalam Majalah dan Tabloid Remaja di Indonesia". PRofesi Humas, 1(1): 35-39.

Winarni, Rina Wahyu. (2010). "Representasi Kecantikan Perempuan dalam Iklan”. Deiksis, 2(2): 134-152.

Wulandari, Ayu dan M. Syam Hamdani. (2017). "Eksploitasi Tubuh Perempuan dalam Iklan (Analisis Semiotika Iklan Televisi Giv Beauty Soap "Tampil Memukau Penuh Pesona”)." Jurnal IImiah Mahasiswa FISIP Unsyiah, 2(4): 371-384. 